\title{
Evaluation of the Curcumin role against cytotoxicity of cadmium chloride in mice
}

\author{
Mohamed Zowail, Khaled Sharafeldin, Asmaa Shahrour \\ Department of Zoology, Faculty of Science, Benha University, Egypt
}

\begin{abstract}
The present study was aimed to evaluate the role of curcumin (CMN) against cytotoxicity of cadmium chloride. Thirty adult male albino mice 3 months old and20-25 grams body weight, were caged into six equal groups. Mice were injected, i.p with $50 \mathrm{mg} \mathrm{CMN} / \mathrm{kg}$ and/or $0.67 \mathrm{mg} \mathrm{CdCl}_{2} / \mathrm{kg}$ b.w for 96h, separately and alternated. The alternated trials were continued for consecutive 8 days.

Results appeared that mice injected with cadmium had significant higher frequency of chromosomal aberrations as fragments, centric fusion, gaps, stickiness and aneuploidy. Also, $\mathrm{CdCl}_{2}$ appeared sperm hummer, without hook, banana and amorphous abnormalities. The administration of CMN improved the frequency of the chromosomal aberrations and sperm abnormalities induced by $\mathrm{CdCl}_{2}$. The administration of $\mathrm{CMN}$ after $\mathrm{CdCl}_{2}$ protects the body from cytotoxicity arising from $\mathrm{CdCl}_{2}$ as well as normal sperm values were recorded. The administration of curcumin before $\mathrm{CdCl}_{2}$ injection did not improve the $\mathrm{CdCl}_{2}$ effect. It could be concluded that the employed dose of CMN protects the body from cytotoxicity arising.
\end{abstract}

Keywords: Cadmium, Curcumin, sperm abnormalities, chromosome aberrations.

\section{INTRODUCTION}

Cadmium is known as one of the most toxic heavy metals. International Agency for Research on Cancer (IARC) has classified cadmium as, Group I, carcinogen (IARC, 2004 and De Sousa Viana et al., 2011). Human exposure to $\mathrm{Cd}$ can occur by food (the highest average of concentrations are found in Molluscs, kidneys, liver, cereals, cocoa and leafy vegetables), water, smoking cigarette and uses of cadmium and cadmium-based products such as television phosphors, a pigment in paints, plastics and plasters (Singh et al., 2012; Ashraf, 2012 and Ogungbe and Lawal, 2008). Cadmium is known to be the most harmful heavy metal it causes various diseases such as arteriosclerosis, osteomalacia, hypertension, osteoporosis, cancer and anemia 
(Obianime and Roberts, 2009). The possible mechanism of cadmium induced toxicity is oxidative stress, generation of reactive oxygen species (ROS) resulting in oxidative deterioration of lipids, proteins and DNA consequently, initiating various pathological conditions in humans and animals (Cuypers et al., 2010). So, to relieve $\mathrm{Cd}$ adverse effect the antioxidants induction is considered as an important therapeutic approach (Renugadevi and Prabu, 2010).

Curcumin, a polyphenolic substance derived from Curcuma longa In India since times immemorial the powered form of dried Curcuma. It is a mandatory spice present in every Indian kitchen. Curcumin has been shown to have a wide spectrum of biological actions, these includes anti-inflammatory, anti-carcinogenic, anti-mutagenic and antibacterial activities and given the designation of super antioxidant and in some experiments, it has been shown to be 300 times more potent than vitamin E. (Singh et al., 2007).

\section{Animals}

\section{MATERIALS AND METHODS}

In this study thirty adult Swiss albino mice (Mus musculus) were used, varying from $20-25 \mathrm{gm}$ in weight and aged three month old. Mice were obtained from the National Research Center (N.R.C.), (Dukki, Cairo, Egypt) were caged individually under standard conditions of light, temperature, humidity and fed with standard pellet diet and water ad libitum.

\section{Chemical and natural:}

Cadmium was used in the formed of cadmium chloride $\left(\mathrm{CdCl}_{2}\right)$ (Oxford Laboratory, Mumbai, India), with concentration of $0.67 \mathrm{mg} / \mathrm{kg}$ or $1 / 10 \mathrm{LD}_{50}$ according to Bench et al. (1999). Curcumin (CMN) (common curcumin powder) which was purchased from local market was used in concentration of $50 \mathrm{mg} \mathrm{CMN} / \mathrm{kg} \mathrm{b}$. w. according to Mohammed (2013). Curcumin crystalline: $\mathrm{C}_{21} \mathrm{H}_{2} \mathrm{OO}_{6}$, Molecular weight $=368.39$. Minimum assay (acidimetric) $99 \%$. Melting point $=170-180^{\circ} \mathrm{C}$.

\section{Dosage and treatments}

The experimental animals were categorized in 6 equal groups, 5 animals each. Group I was used as untreated negative control. Group II, (control +), was i.p injected with $0.5 \mathrm{ml}$ saline solution daily for $96 \mathrm{hs}$. Group III, was i.p injected with $0.67 \mathrm{mg} \mathrm{CdCl} / \mathrm{kg}$ b.w. dissolved in $0.5 \mathrm{ml}$ saline solution as a single dose and give for $96 \mathrm{hs}$. Group IV, was injected i.p, with $50 \mathrm{mg} \mathrm{CMN} / \mathrm{kg}$ b.w. dissolved in $0.5 \mathrm{ml}$ saline solution daily for $96 \mathrm{hs}$. Group V, was injected i.p with CMN daily for $96 \mathrm{hs}$, then single dose of $\mathrm{CdCl}_{2}$ for $96 \mathrm{hs}$ (as a protective trial), Group VI, was i.p, injected with $\mathrm{CdCl}_{2}$ for $96 \mathrm{hs}$ as single dose then followed by 4 consecutive Curcumin doses, for $96 \mathrm{hs}$, (as a treatment trial). 


\section{Cytogenetically study}

Colchicine was injected intraperitoneally $2-3 \mathrm{hrs}$. before sacrificing animals. Bone-marrow was extracted from femur bone and metaphases were shown according to the method of Yosida and Amano (1965). The preparations of mitotic chromosome were made according to Ford and Hamerton (1956). Giemsa stain (7\%) in phosphate buffer (pH 6.8) was used for slides. Hundred spreads metaphases per animal were investigated for chromosomal aberration analysis.

\section{Sperm head morphology assay}

Cauda epididymides were excised and both epididymides were minced together in isotonic medium then filtered to exclude large fragments. The cells' Smears were prepared and 5\% Eosin Y stained (aqueous). Light microscope (100x), green filter was used to examine smears. Thousand sperms were assessed for each animal to investigate the morphology of sperm abnormality according to the criteria of Wyrobek and Bruce (1975). Any overlay or contact sperms or heads without tails were ignored.

\section{Statistical analysis}

Mean $\pm \mathrm{SE}$ was expressed to all values where 5 animals were evaluated, $\mathrm{n}=5$, in each group. Statistical analysis of cytogenetic was performed on SPSS software (version 18) using one-way ANOVA test. Significance was considered when $\mathrm{P}$ values less than 0.05 .

\section{RESULTS}

Various chromosomal aberrations were observed in the bone marrow cells of albino mice injected with cadmium. These were of structural and numerical type, were identified and quantitated relative to non-treated control.

Structural aberration included chromatid deletions (Fig. Ib); fragments (Fig. Ic); centric fusion (Fig. Id); centromeric attenuation (Fig. If); end to end (Fig. Ig); rings (Fig. Ih); polyploidy (Fig. Ii); stickiness (Fig. Ij). A chromatid was considered to have a Gap when it had an unstained area shorter than its diameter or equal to it, and a break was also scored when a chromatid was markedly shorter than its sister chromatid. End to end association was scored when two chromatids of different chromosomes appeared attached this could result from reciprocal translocation or stickiness. The stickiness is considered as assort of chromosomal agglutination of unknown nature which resulted in a pycnotic or sticky appearance of chromosome.

Figure (2) shows shaped sperms (a) Normal sperm, (b) Hummer sperm, (c) Without hook, (d) Banana shape.

As shown in table (1), the mean number nuclei with chromosomal aberration in mice treated with cadmium appear high significant of chromosomal aberrations in all animals compared with control. The more types of aberration appeared with chromosomal fragments, centric fusion, gaps, 
stickiness and aneuploidy. Also, the mitotic activity shows decrease in the treated groups with cadmium chloride when compare to control.

Table (2) incidence of total abnormal shaped sperms per thousand treated with $\mathrm{Cd}$ and $\mathrm{CMN}$ which include Hummer sperm, without hook, amorphous, Banana shape.

Table (1): Average of chromosomal aberration and mitotic index in bone marrow cells of male mice treated with $\mathrm{Cd}$ and $\mathrm{CMN}$.

\begin{tabular}{|c|c|c|c|c|c|c|c|c|c|c|c|}
\hline 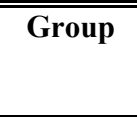 & $\begin{array}{c}\text { Deletio } \\
\mathbf{n}\end{array}$ & $\begin{array}{c}\text { Fragm } \\
\text { ent }\end{array}$ & $\begin{array}{c}\text { Centri } \\
\text { c } \\
\text { fusion }\end{array}$ & $\begin{array}{c}\text { Centromeric } \\
\text { attenuation }\end{array}$ & $\begin{array}{c}\text { End } \\
\text { to end }\end{array}$ & $\overline{\text { Gap }}$ & $\begin{array}{c}\text { Stickin } \\
\text { ess }\end{array}$ & $\begin{array}{c}\text { Trisom } \\
\mathbf{y}\end{array}$ & Total & $\%$ & $\begin{array}{c}\text { Mitoti } \\
\mathrm{c} \\
\text { index } \\
\end{array}$ \\
\hline \multirow[t]{2}{*}{ Control } & $6.8 \pm 0.4$ & $3.0 \pm 0.5$ & $8.2 \pm 0.7$ & $4.2 \pm 0.4$ & $\begin{array}{c}1.6 \pm 0 . \\
5\end{array}$ & $0.0 \pm 0.0$ & $0.0 \pm 0.0$ & $0.2 \pm 0.8$ & $\begin{array}{c}24 \pm 3 . \\
3\end{array}$ & $\begin{array}{r}2 . \\
4\end{array}$ & $\begin{array}{r}292.6 \\
\pm 12.5\end{array}$ \\
\hline & $\begin{array}{c}\text { b,c,d,f, } \\
\text { g,h,i }\end{array}$ & $\mathrm{b}, \mathrm{e}$ & $\mathrm{d}, \mathrm{e}$ & $\mathrm{d}, \mathrm{i}$ & & $\mathrm{e}$ & $e, f, i$ & $e, g$ & $\mathrm{e}, \mathrm{i}$ & & $\begin{array}{l}\mathrm{e}, \mathrm{g}, \\
\mathrm{h}, \mathrm{i}\end{array}$ \\
\hline \multirow[t]{2}{*}{ Control+ } & $1.6 \pm 0.5$ & $5.8 \pm 0.7$ & $8.6 \pm 1.0$ & $5.0 \pm 0.7$ & $\begin{array}{c}0.2 \pm 0 . \\
2\end{array}$ & $0.0 \pm 0.0$ & $0.0 \pm 0.0$ & $0.2 \pm 0.6$ & $\begin{array}{c}21.4 \pm \\
3.7\end{array}$ & $\begin{array}{c}2 . \\
1\end{array}$ & $\begin{array}{c}263 \pm \\
17.1\end{array}$ \\
\hline & a,c,e,g,i & $\begin{array}{c}\mathrm{a}, \mathrm{c}, \mathrm{d}, \mathrm{f}, \\
\mathrm{g}, \mathrm{h}, \mathrm{i}\end{array}$ & $\mathrm{C}, \mathrm{d}, \mathrm{e}$ & $\mathrm{i}$ & $\begin{array}{c}\mathrm{C}, \mathrm{e}, \mathrm{f}, \mathrm{g} \\
\mathrm{i}, \mathrm{i}\end{array}$ & $\mathrm{e}$ & $e, f, i$ & $e, g$ & $\mathrm{e}$ & & $\begin{array}{l}\mathrm{e}, \mathrm{g}, \\
\mathrm{h}, \mathrm{i}\end{array}$ \\
\hline \multirow[t]{2}{*}{ CMN } & $2.6 \pm 1.0$ & $5.0 \pm 0.7$ & $4.6 \pm 0.9$ & $6.6 \pm 0.5$ & $\begin{array}{c}1.0 \\
\pm 0.4\end{array}$ & $0.0 \pm 0.0$ & $0.0 \pm 0.0$ & $2.0 \pm 0.7$ & $\begin{array}{c}21.8 \pm \\
4.2\end{array}$ & $\begin{array}{c}2 . \\
1\end{array}$ & $\begin{array}{l}263.2 \\
\pm 8.2\end{array}$ \\
\hline & $\mathrm{a}, \mathrm{e}, \mathrm{i}$ & $\mathrm{b}$ & a,b,e,f,i & $\mathrm{a}, \mathrm{c}, \mathrm{f}, \mathrm{g}$ & & $\mathrm{e}$ & $e, f, i$ & $e, g$ & $\mathrm{e}$ & & $\begin{array}{l}\text { e, g, } \\
h, i\end{array}$ \\
\hline \multirow[t]{2}{*}{ Cd } & $5.6 \pm 0.6$ & $6.8 \pm 0.4$ & $\begin{array}{c}11.8 \pm 1 . \\
5\end{array}$ & $5.0 \pm 0.5$ & $\begin{array}{c}2.2 \pm 0 . \\
4\end{array}$ & $0.4 \pm 0.2$ & $1.0 \pm 0.3$ & $1.4 \pm 0.3$ & $\begin{array}{c}34.2 \pm \\
4\end{array}$ & $\begin{array}{l}3 . \\
4\end{array}$ & $\begin{array}{c}174 \pm \\
12.1\end{array}$ \\
\hline & $\begin{array}{l}\text { b,c,d,f, } \\
\text { g,h }\end{array}$ & $a, g, i$ & $\begin{array}{c}\text { a,b,c,d, } \\
\text { f,g,h,i }\end{array}$ & $\mathrm{i}$ & $\mathrm{b}$ & $\begin{array}{c}\mathrm{a}, \mathrm{b}, \mathrm{d}, \mathrm{f}, \\
\mathrm{g}, \mathrm{h}\end{array}$ & $\begin{array}{c}\mathrm{a}, \mathrm{b}, \mathrm{c}, \\
\mathrm{d}\end{array}$ & $\begin{array}{c}\mathrm{a}, \mathrm{b}, \mathrm{c}, \\
\mathrm{d}\end{array}$ & $\begin{array}{l}\mathrm{a}, \mathrm{b}, \\
\mathrm{c}, \mathrm{d}, \mathrm{f}, \\
\mathrm{g}, \mathrm{h}\end{array}$ & & $\begin{array}{l}\mathrm{a}, \mathrm{b}, \\
\mathrm{c}, \mathrm{d}, \mathrm{f}\end{array}$ \\
\hline \multirow[t]{2}{*}{ CdCMN } & $\begin{array}{c}3.4 \\
\pm 1.1\end{array}$ & $3.2 \pm 1.0$ & $7.5 \pm 0.9$ & $4.2 \pm 0.9$ & $\begin{array}{c}2.2 \pm 0 . \\
9\end{array}$ & $0.0 \pm 0.0$ & $0.6 \pm 0.4$ & $1.4 \pm 0.9$ & $\begin{array}{c}22.5 \pm \\
6.1\end{array}$ & $\begin{array}{l}2 . \\
2\end{array}$ & $\begin{array}{c}209 \pm \\
14.5\end{array}$ \\
\hline & a,b,e & $\mathrm{b}, \mathrm{e}$ & $\mathrm{e}, \mathrm{i}$ & $\mathrm{d}, \mathrm{i}$ & $\mathrm{b}$ & $\mathrm{e}$ & & $a, b, e, d$ & $\mathrm{e}$ & & $\begin{array}{l}\mathrm{a}, \mathrm{b}, \\
\mathrm{c}, \mathrm{d}, \mathrm{f}\end{array}$ \\
\hline \multirow[t]{2}{*}{ CMNCd } & $\begin{array}{l}4.4 . \\
\pm 0.5 \\
\end{array}$ & $3.2 \pm 0.9$ & $8.0 \pm 1.1$ & $8.0 \pm 1.3$ & $\begin{array}{c}1.8 \pm 0 . \\
4\end{array}$ & $0.2 \pm 0.2$ & $0.8 \pm 0.4$ & $1.0 \pm 0.2$ & $\begin{array}{c}27.4 \pm \\
5.0\end{array}$ & $\begin{array}{l}2 . \\
7\end{array}$ & $\begin{array}{r}194.6 \\
\pm 10.2\end{array}$ \\
\hline & $\begin{array}{c}\text { a,b,d,f, } \\
\text { h }\end{array}$ & $\mathrm{b}, \mathrm{e}$ & C,d,e,g & a,b,c,e,f,g & $\mathrm{b}$ & & $\mathrm{a}, \mathrm{b}, \mathrm{c}, \mathrm{d}$ & & $\mathrm{a}$ & & $\begin{array}{l}\mathrm{a}, \mathrm{b}, \\
\mathrm{c}, \mathrm{d}, \mathrm{f}\end{array}$ \\
\hline
\end{tabular}

a; significant with control, b; significant with control + , c; significant with $\mathrm{CMN}$, d; significant with $\mathrm{Cd}$, e; significant with $\mathrm{Cd} C M N$, f; significant with CMN Cd. Significant means $\mathrm{P}<0.05$. 
Table (2) incidence of total abnormally shaped sperms per thousand treated with $\mathrm{Cd}$ and $\mathrm{CMN}$.

\begin{tabular}{|c|c|c|c|c|c|c|c|}
\hline \multirow[t]{2}{*}{ Groups } & \multirow[t]{2}{*}{ Normal sperm } & Hummer & Banana & Amorphous & $\begin{array}{c}\text { Without } \\
\text { hook }\end{array}$ & \multirow[t]{2}{*}{ Total } & \multirow[t]{2}{*}{$\%$} \\
\hline & & Sig & Sig & Sig & Sig & & \\
\hline \multirow[b]{2}{*}{ control } & \multirow[b]{2}{*}{$902 \pm 4$} & $13.0 \pm 1.0$ & $38.0 \pm 2.9$ & $16 \pm 2.3$ & $31 \pm 2.0$ & \multirow[b]{2}{*}{$98.0 \pm 12.2$} & \multirow[b]{2}{*}{9.8} \\
\hline & & & $\mathrm{c}, \mathrm{d}, \mathrm{g}, \mathrm{i}$ & $\overline{\mathrm{i}}$ & $\mathrm{c}, \mathrm{d}, \mathrm{e}, \mathrm{h}, \mathrm{i}$ & & \\
\hline \multirow[b]{2}{*}{ Control+ } & \multirow[b]{2}{*}{$902 \pm 4$} & $14.2 \pm 3.1$ & $35.0 \pm 2.8$ & $15 \pm 5.3$ & $32 \pm 3.0$ & \multirow[b]{2}{*}{$96.2 \pm 18.2$} & \multirow[b]{2}{*}{9.62} \\
\hline & & & $\mathrm{c}, \mathrm{d}, \mathrm{g}, \mathrm{i}$ & $\mathrm{i}$ & $\mathrm{c}, \mathrm{d}, \mathrm{e}, \mathrm{h}, \mathrm{i}$ & & \\
\hline \multirow[b]{2}{*}{ CMN } & \multirow[b]{2}{*}{$933 \pm 12$} & $16.2 \pm 4.0$ & $18.4 \pm 4.5$ & $18 \pm 2.7$ & $14 \pm 2.0$ & \multirow[b]{2}{*}{$66.6 \pm 25.2$} & \multirow[b]{2}{*}{6.66} \\
\hline & & $\bar{i}$ & $\mathrm{a}, \mathrm{b}, \mathrm{e}, \mathrm{f}, \mathrm{h}, \mathrm{i}$ & $\bar{i}$ & $\mathrm{a}, \mathrm{b}, \mathrm{e}, \mathrm{f}, \mathrm{h}, \mathrm{i}$ & & \\
\hline \multirow[b]{2}{*}{ Cd } & \multirow[b]{2}{*}{$878 \pm 9$} & $17.4 \pm 2.0$ & $46.8 \pm 4.1$ & $18 \pm 2.6$ & $45 \pm 2.0$ & \multirow[b]{2}{*}{$127.2 \pm 19.7$} & \multirow[b]{2}{*}{12.7} \\
\hline & & $\mathrm{h}, \mathrm{i}$ & $\mathrm{c}, \mathrm{d}, \mathrm{g}$ & $\mathrm{i}$ & $\mathrm{a}, \mathrm{b}, \mathrm{e}, \mathrm{f}, \mathrm{g}, \mathrm{i}$ & & \\
\hline \multirow[b]{2}{*}{ Cd CMN } & \multirow[b]{2}{*}{$894 \pm 11$} & $13.4 \pm 1.0$ & $22.6 \pm 5.5$ & $17 \pm 2.2$ & $23 \pm 6.0$ & \multirow[b]{2}{*}{$76.0 \pm 14.7$} & \multirow[b]{2}{*}{7.60} \\
\hline & & & $\mathrm{a}, \mathrm{b}, \mathrm{e}, \mathrm{f}, \mathrm{h}, \mathrm{i}$ & $\mathrm{i}$ & $\mathrm{e}, \mathrm{h}, \mathrm{i}$ & & \\
\hline \multirow[b]{2}{*}{ CMN Cd } & \multirow[b]{2}{*}{$845 \pm 3$} & $8.0 \pm 1.0$ & $53.6 \pm 4.5$ & $39.6 \pm 4.0$ & $58 \pm 3.0$ & \multirow[b]{2}{*}{$159.2 \pm 12.5$} & \multirow[b]{2}{*}{15.9} \\
\hline & & $\mathrm{d}, \mathrm{e}, \mathrm{f}$ & $\mathrm{a}, \mathrm{b}, \mathrm{c}, \mathrm{d}, \mathrm{f}, \mathrm{g}, \mathrm{h}$ & $\mathrm{a}, \mathrm{b}, \mathrm{c}, \mathrm{d}, \mathrm{e}, \mathrm{f}, \mathrm{g}, \mathrm{h}$ & $\mathrm{a}, \mathrm{b}, \mathrm{c}, \mathrm{d}, \mathrm{f}, \mathrm{g}, \mathrm{h}$ & & \\
\hline
\end{tabular}

a; significant with control, b; significant with control + , c; CMN, d; significant with $\mathrm{Cd}$, e; significant with $\mathrm{Cd} \mathrm{CMN}$, f; significant with $\mathrm{CMN} \mathrm{Cd}$. Significant means $\mathrm{P}<0.05$. 


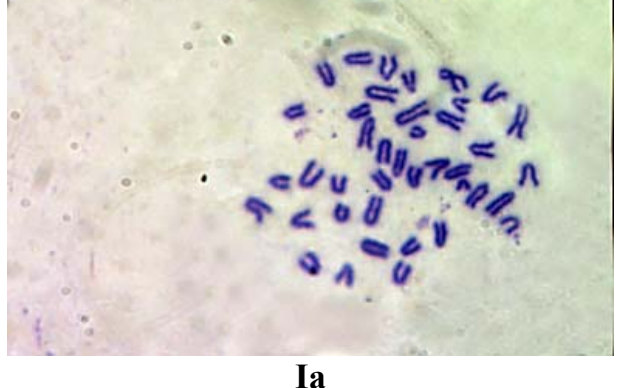

Ia
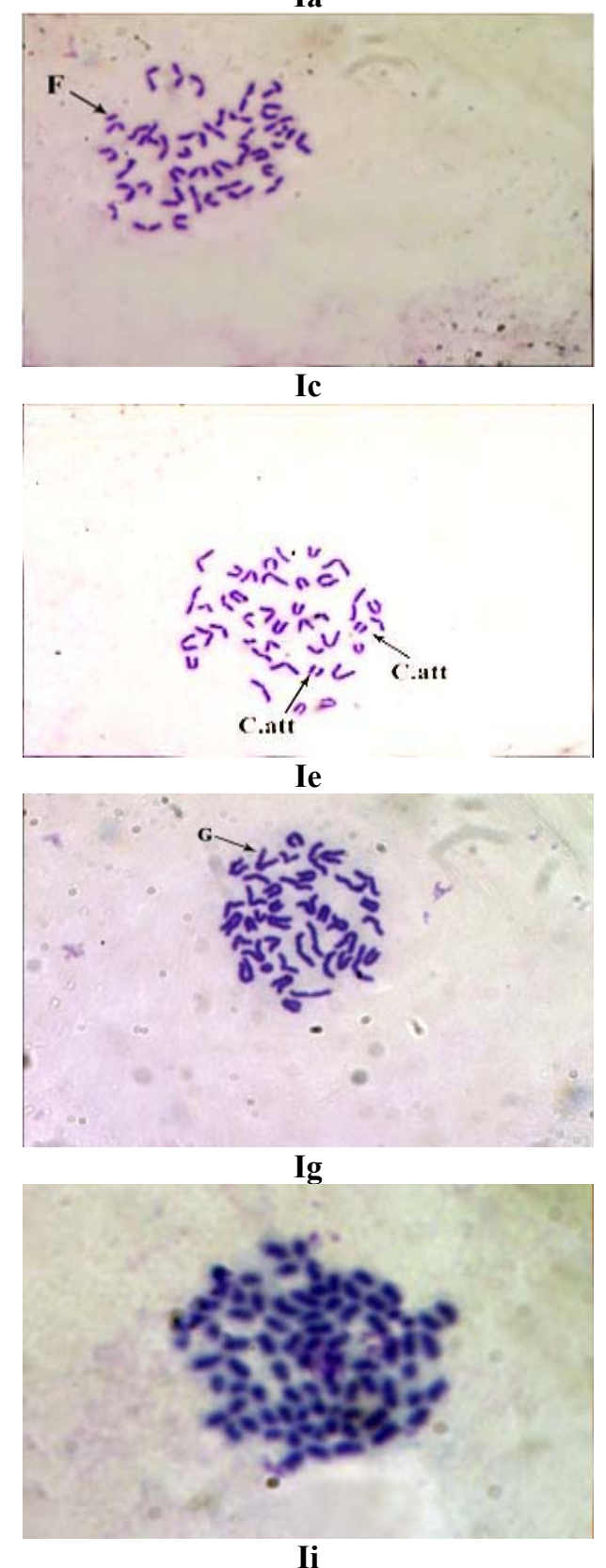

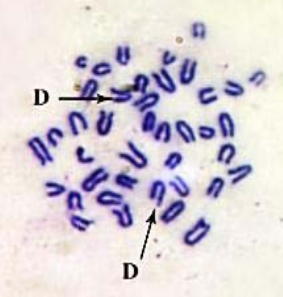

Ib

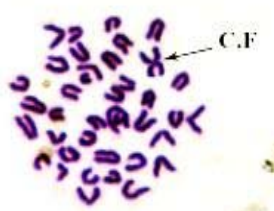

Id

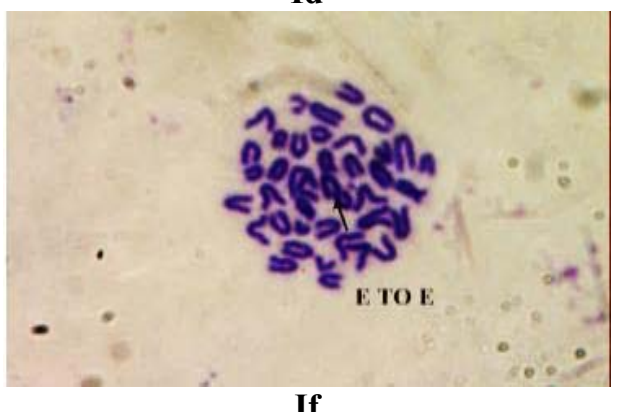

If

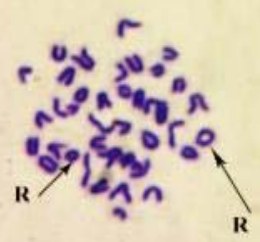

Ih

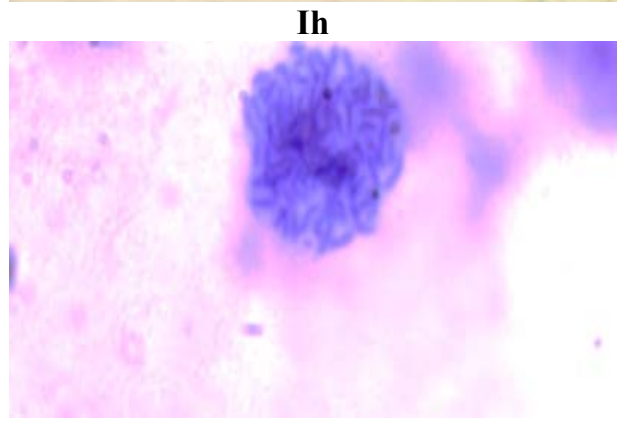

Ij

Figure (1): Metaphase spread from mouse bone marrow cells showing (a) normal chromosomes spread, (b) deletion (D), (c) fragment (F), (d) centric fusion (C.F), (e) centromeric attenuation (C.A), (F) end to end (E.to end), (g) gap, (h) ring (R), (i) polyploidy, (j) stikiness. 


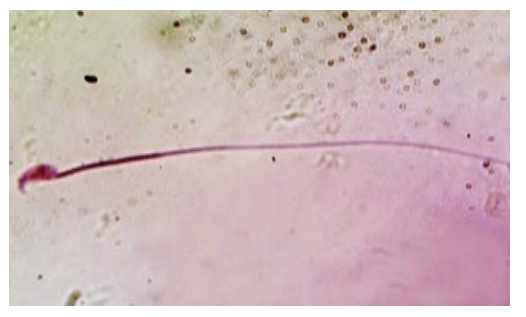

a

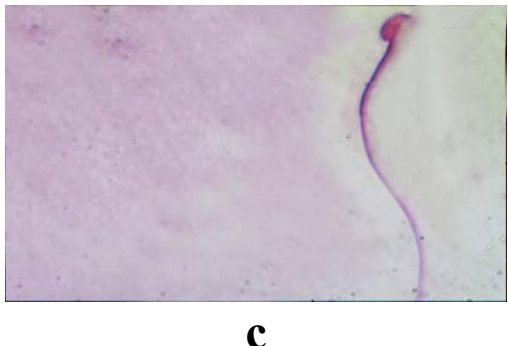

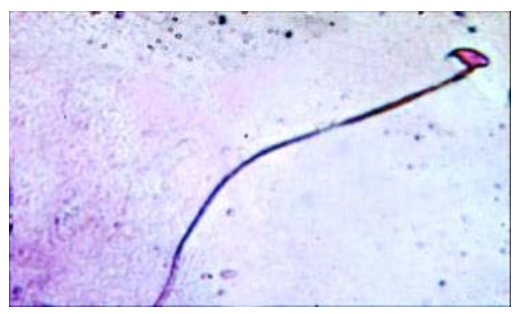

b

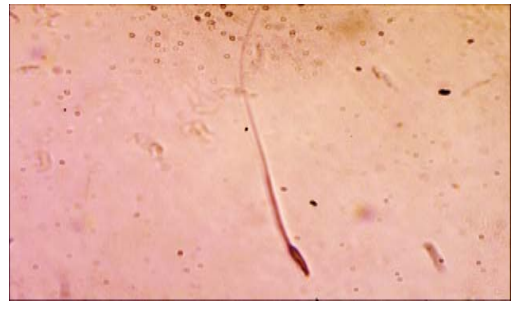

d

Figure (2): It shows (a) Normal sperm, (b) Hummer sperm, (c) Without hook, (d) Banana shape.

\section{DISCUSSION}

Cd burden has been correlated with chromosomal aberrations (IARC, 1993). It was observed that, chromosomal fragments, centric fusion, gaps, stickiness and aneuploidy produced by $\mathrm{Cd}$ injection, were also in $\mathrm{O}$. mossambica (Chandra and Khuda-Bukhsh, 2004). Singh et al. (2007) showed that low dose of $\mathrm{Cd}(1 \mathrm{mg} / \mathrm{kg} / \mathrm{day})$ for 30 days resulted in chromosomal aneuploidy, breaks, gaps and centromeric fusion. However, dose of $25 \mathrm{mg}$ and $200 \mathrm{mg} \mathrm{Cd}$ $/ \mathrm{kg} /$ day for 20 and 5 days resulted in severe damage of chromosome. Singh and Sankhla (2010) have assured that $\mathrm{Cd}$ increased the number of chromosomal aberrations and declined the mitotic index. Shaikh et al. (1999) referred that damage of chromosome to stimulation of free radical which in turn declined mitotic index. The present study significant decrease in sperm count associated with significant increase in sperm abnormalities in $\mathrm{Cd}$ treated mice. The abnormalities included hummer, without hook, amorphous and banana. The Cd-induced ROS may affect the specific gene loci of germ cell chromosomes that may dysfunction the maintenance of normal sperm structure. The same result was explained by Acharya et al. (2003) ; Oldereid et al. (1994) and Salama and EL-Baher (2007) in Cd-treated mice due to either membranous or macromolecular damage. As well as, the decreased sperm count and alterations in motility have been associated with cigarette (Kulikauskas et al., 1985). Authors found that cadmium induced spermatogenic damage, decreased sperm count, reduced testosterone level due to generation of free radicals. Zemjanis (1970), Chandra and KhudaBukhsh (2004) and Kini et al. (2012), reported that spermatozoa 
abnormalities such as headless tails and bent mid-piece are considered to reflect disturbances to spermatogenesis. Whereas secondary abnormalities such as bent tails and abnormal acrosome are believed to arise after spermatogenesis is completed due to epididymal dysfunction. Thus, the increase in abnormal sperms in the cadmium-treated rats may be due to both testicular dysfunction and impairment of epididymal function. Oliveira et al. (2009) also demonstrated that $\mathrm{Cd}$ induced increase in the percentage of cells with abnormal head and tail morphology. Bekheet (2010) pointed out that Cd-induced loss of spermatogenic cells has appeared by apoptosis and structural ultra-changes in the Sertoli and spermatogenic cells cytoplasm. The intake of low and oral doses of cadmium over a long period of time induces quantitative changes in apoptosis of the seminiferous epithelium of the rats (Herranz et al., 2010). Even a low level of cadmium accumulation in semen might contribute to male infertility by reducing sperm quality (Wu et al., 2008).

Currently, decreased chromosome abnormalities and mitotic index were observed in $\mathrm{CMN}$-treated group and cadmium then curucmin as treatment trial $(\mathrm{Cd} \mathrm{CMN})$ in comparison to $\mathrm{Cd}$ group. In contrast, curcumin then cadmium as protection trial (CMNCd) group has the same values of $\mathrm{Cd}$ in chromosome abnormalities. The present experiment confirms the protective role of curcumin in bone marrow cells as shown by (Singh and Sankhla, 2010). Curcumin attenuated the cadmium induced malondialdehyde (MDA) formation and the decreased testicular reduced glutathione (GSH) (both discussed below), possibly due to its intrinsic antioxidant properties. Curcumin may thus prevent per oxidative changes in the sperm and the testicular membrane, thus enhancing sperm motility and decreasing spermatozoa abnormalities. CMN administration after Cd couldn't ameliorate, the effect of $\mathrm{Cd}$. No reduction in cadmium tissue concentration was observed in cadmium exposed animals and cadmium treated with curcumin suggesting that curcumin is devoid of any cadmium removing activity. This may be due to the fact that, the elimination half-life of cadmium is 10-30 years. (Jarup et al., 1998). Hence, may suggest that curcumin may act by mechanisms different from chelation therapeutic approaches. Curcumin as antioxidant may be important in the treatment of cadmium intoxication. Curcumin represents a class of anti-inflammatory and antioxidants reported to be a potent inhibitor of ROS formation (Venkatesan et al., 2000 and Biswas et al., 2005). Thus, it is believed that antioxidant should be one of the important components of an effective therapy of $\mathrm{Cd}$ poisoning. Treatment with curcumin was effective in decreasing oxidative damage induced by $\mathrm{Cd}$ which resulted in markedly lower MDA concentration. Also, in the present study CMN lead to increase in sperm count associated with significant decrease in sperm head abnormalities. In contrast, curcumin then cadmium as trail protect (CMNCd) group has the 
same values of $\mathrm{Cd}$ in both sperm abnormalities. Curcumin may protect from the damaged effect of $\mathrm{Cd}$ on mice testis. Curcumin as a stronger antioxidant may relieve the effect of free radicals induced by $\mathrm{Cd}$ exposure. The administration of curcumin to cadmium-treated rats prevents the cadmium induced chromosomal aberration, spermatogenic damage and decreased sperm count.

\section{REFERENCES}

Acharya, U.R.; Acharya, S. and Mishra, M. (2003). Lead acetate induced cytotoxicity in male germinal cells of Swiss mice. Ind Health, 41(3):291-4.

Ashraf, M .W. (2012). Levels of heavy metals in popular cigarette brands and exposure to these metals via smoking". The Scientific World Journal. 2012: doi:10.1100/2012/729430.

Bekheet, S. H. M., (2010). Cadmium Chloride Rapidly Alters Both BTB Tight Junction Proteins and Germ Cells in Young Rat Testes. Egyption Acadmic Journal of Biology Scicence, 2(1): 59-4.

Bench, G.; Corzett, M.H.; Martinelli, R. and Balhorn, R. (1999). Cadmium Concentrations in the Testes, Sperm and permatids of Mice Subjected to Long-Term Cadmium Chloride Exposure. Journal of Cytometry, 35:30-36.

Biswas, S.K.; meclure, D.; Jimenez, L.A.; Megson, I.L. and Rahman, I. (2005).Curcumin induces glutathione biosynthesis and inhibits nfkappab activation and interleukin-8 release in alveolar epithelial cells: mechanism of free radical scavenging activity. Antioxid. Redox Signal, 7:32-41.

Chandra, P. and Khuda-Bukhsh, A. (2004). Genotoxic effects of cadmium chloride and azadirachtin treated singly and in combination in fish. Ecotoxicology and environmental safety, 58(2):194-201.

Chapin, R.E.; Harris, M.W.; Davis, B.J.; Ward, S.M.; Wilson, R.E.; Mauney, M.A.; Lockhart, A.C.; Smialowicz, R.J.; Moser V.C.; Burka L.T. and Collins B.J., (1997). The effects of perinatal juvenile methoxychlor exposure on adult rat nervous, immune, and reproductive system function. Toxicology, 40:13857.

Cuypers, A.; Plusquin, M.; Remans, T.; Jozefczak, M.; Keunen, E.; Gielen, H.; Opdenakker, K.; Nair, A.R.; Munters, E.; Artois, T.J.; Nawrot, T.; Vangronsveld, J. and Smeets, K. (2010). Cadmium stress: an oxidative challenge. Bimetals, 23: 927-40.

De Sousa Viana, G. F.; Garcia, K. S. and Menezes-Filho, J. A. (2011). Assessment of carcinogenic heavy metal levels in Brazilian cigarettes. Environmental Monitoring and assessment, 181: 255-265. 
Ford, C. and Hamerton, J. (1956). A colchicine, hypotonic citrate, squash sequence for mammalian chromosomes. Stain technology, 31(6):247251.

Herranz, L. M.; Teba, F.; Martín, R.; Ingelmo, I.; Gómez, V.; Codesal, J.; Pozuelo, M.; Oltra, B.; Serna, E. and Santamaría, L. (2010). Quantitative Changes in Rat Seminiferous Epithelium After Chronic Administration of Low Doses of Cadmium and Zinc: A Stereological Study. The Open Andrology Journal, 2: 27-36.

International Agency for Research on Cancer (IARC) (2004). Inorganic and organic lead compounds, IARC monographs on the evaluation of carcinogenic risks to humans, 87.

IARC, (1993). Beryllium, cadmium, mercury, and exposures in the glass manufacturing industry. Working Group views and expert opinions, Lyon, 9-16 February 1993. IARC Monographas and Evaluation of Carcinogenic Risks Human, 58:1-415. PMID: 8022054.

Jarup, L.; Berglund, M.; Elinder, C.G.; Nordberg, G. and Vahter, M. (1998). Health effects of cadmium exposure- A review of the literature and a risk estimate". Scand. Journal of Work Environmental Health, $24: 1-51$

Kini, R.D.; Tripathi, Y.; Raghuveer, C.V.; Pai, S. R. and Nayanatara, A.K. (2012). Effect of $\alpha$-Tocopherol Pretreatment on Epididymal Weight, Sperm Count \& Sperm Morphology on Cadmium Induced Testicular Damage in Male Albino Rats. International Journal Plant, Animal and Environmental Sciences g 2: 110-114.

Kulikauskas, V.; Blaustein, D. and Ablin, R.J. (1985). Cigarette smoking and its possible effects on sperm. Fertility and sterility, 44(4):526-528.

Mohammed, M.S., (2013). In vivo cytogenetic and genotoxic effects of curcumin on mouse bone marrow. Al-Qadisiah Medical Journal, 9: (16).

Obianime, A.W. and Roberts, I.I. (2009). Antioxidants, cadmium-induced toxicity, serum biochemical and histological abnormalities of the kidney and testes of the male wistar rats. Nigerian Journal Physiological Sciences, 24(2): 177-185.

Ogungbe, I.V. and Lawal, A.O. (2008). The protective effects of ethanolic extract of garlic and ascorbic acid on cadmium-induced oxidative stress. Journal of Biology Sciences, 8: 181-185.

Oldereid, N.; Thomassen, Y. and Purvis, K. (1994). Seminal plasma lead, cadmium and zinc in relation to tobacco consumption. Interenational Journal of andrology, 17(1):24-28.

Oliveira, H.; Spanò, M.; Santos, C. and Pereira, M. L. (2009). Adverse Effects of Cadmium Exposure on Mouse Sperm. Reproductive Toxicology, 28: 550-555. 
Renugadevi, J. and Prabu, S.M. (2010). Cadmium-induced hepatotoxicity in rats and the protective effect of naringenin. Experimental and Toxicology Pathology, 62(2): 171-181.

Salama, A.F. and El-Bahr, S.M. (2007). Effect of Curcumin on CadmiumInduced Oxidative Testicular Damage in Rats. Journal of Medical Research Institute, 28 (2): 167-73.

Shaikh, Z.A.; Zaman, K.; Tang, W. and Vu, T. (1999). Treatment of chronic cadmium nephrotoxicity by $\mathrm{N}$-acetyl cysteine. Toxicology letters, 104(1):137-142.

Singh, P.; Chaudhary, S.; Patni, A. and Sankhla, V. (2007). Effect of cadmium chloride induced genotoxicity in bone marrow chromosomes of swiss albino mice and subsequent protective effects of Emblica officinalis and vitamin C. Journal of Herbal Medical and Toxicology, 1(2): 67-71.

Singh, P. and Sankhla, V. (2010). In situ protective effect of curcumin on cadmium chloride induced genotoxicity in bone marrow chromosomes of Swiss albino mice. Journal of Cell Molecular Biology, 8:57-64.

Singh, P.; Mogra, P.; Bano, H.; Sankhla, V.; Deora, K.; Barolia, S. and Javeria, S. (2012). Protective and preventive effects of curcumin against cadmium chloride induced gastrointestinal toxicity in Swiss albino mice. World Journal of Science Technology, 2(12):10-17.

Venkatesan, N.; Punithavathi, D. and Arumugan, V. (2000). Curcumin prevents adriamycin nephrotoxicity in rats. British Journal of Pharmacology, 12:231-234.

Wyrobek, A. and Bruce, W. (1975). Chemical induction of sperm abnormalities in mice". Proceedings of the National Academy of Sciences, 72(11):4425-4429.

Yosida, T.H. and Amano, K. (1965). Autosomal polymorphism in laboratory bred and wild Norway rats. Rattus norvegicus, found in Misima. Chromosoma, 16(6):658-667.

Zemjanis, R. (1970). Collection and evaluation of semen. Baltimore MD (2nd Ed) In: Diagnostic and Therapeutic Technique in Animal Reproduction.William and Wilkins Company, 139-53.

Wu, H.M.; Lin-Tan, D.T.; Wang, M.L., Huang, H.Y.; Wang, H.S.; Soong, Y.K. and Lin, J.L. (2008). Cadmium Level in Seminal Plasma may Affect the Pregnancy Rate for patientsundergoing Infertility Evaluation and Treatment. Reprod Toxicology , 25(4):481-484. 
تقييم دور الكركم ضد السمية الخلوية لكلوريد الكادميوم في الفئران

محمد زويل ، خالد شرف الاين ، أسماء شحرور

قسم علم الحيو ان- كليه العلوم - جامعه بنها - مصر

تهدف الدراسة إلى تقييم دور الكركم (CMN) ضد السميه الخلويه لكلوريد الكادميوم. حيث تم تقسيم ثلاثثن من الذكور الفئران البالغين إلى ست مجموعات. تم حقنها في التجويف البرويتوني بخمسين ملجم كركم / كجم و V7, • ملجم لكلوريد الكادميوم /كجم لمده 99 اساعه، على حدة او بالتناوب لمده 1 أيام. أظهرت النتائج أن حقن الفئران بالكادميوم ادي الي زياده معدل التشوهات الكروموسوميه مثل الثظايا، الالتحام السنتروميري لكرومسومين مختلفين، الفجوة، اللزوجه و عدم توازن ،الصبغيات متمثلا في التثلث الصبغي،. كما يسبب كلوريد الكادميوم الحيوانات المنوية شكل المطرقه، بدون خطاف وشكل موزه وتشوهات غير منتظمه. وأظهرت ايضا ان الكركم له تأثير في تحسين وتيره التشو هات الصبغية والحيو انات المنوية الناتجة عن كلوريد الكادميوم وهذا بدل علي ان الكركم بعد كلوريد الكادميوم يحمي الجسم من السمية الخلوية الناتجة عن كلوريد الكادميوم وايضا تحسين قيم الحيو انات المنوية المسجله. تناول الكركم قبل الحقن بكلوريد الكادميوم يلغي تأثيركلوريد الكادميوم. و علية يمكننا استنتاج ان الجرعه المستخدمه من الكركم يمكن استخدمها لحمايه الجسم من السميه الخلويه الناتجه عن كلوريد الكادميوم 